\title{
Perancangan Video Infografis Bahaya Merokok untuk Anak SD Menggunakan Teknik Motion Graphics
}

\author{
Nindi Oktaviani ${ }^{1}$, Nira Rusanti ${ }^{2}$, Faldi Hendrawan ${ }^{3}$, Widya Adhariyanty Rahayu ${ }^{4}$ \\ ${ }^{1,2,3}$ Desain Komunikasi Visual, ${ }^{4}$ Informatika \\ 1nindiokta14@gmail.com, ${ }^{2}$ nira.rusanti@gmail.com, ${ }^{3}$ faldikobenasia@gmail.com, \\ ${ }^{4}$ widyariyanty@gmail.com
}

\begin{abstract}
ABSTRAK
Kesehatan merupakan aspek yang sangat penting dalam kehidupan manusia. Saat ini, banyak penyakit yang disebabkan tidak hanya melalui kuman atau bakteri, melainkan dari kebiasaan atau pola hidup yang tidak sehat. Merokok adalah salah satu kebiasaan atau pola hidup yang tidak sehat. Merokok dapat menimbulkan penyakit karena di dalam rokok terdapat zat kimia berbahaya yang mengandung racun. Bahaya merokok akan meningkat apabila dilakukan pada usia yang lebih muda yaitu anak SD. Bila anak-anak tumbuh menjadi perokok maka bahaya kesehatan muncul semakin besar. Upaya untuk mencegah kebiasaan merokok ini dapat dilakukan dengan berbagai media, salah satunya adalah media video infografis.

Untuk membuat sebuah video infografis perlu adanya pencarian data, yaitu melalui wawancara dan studi pustaka. Dalam sebuah proses perancangan yang dibuat terdapat dasar pemikiran bagaimana membuat sebuah video infografis yang dapat menarik anak SD dan mampu memahami isi video tersebut, yaitu dengan cara menonjolkan ilustrasi, animasi dengan bahasa dan gambar yang mudah dipahami. Dengan ditunjang teknik motion graphics maka pembuatan video ini akan semakin menarik. Video infografis merupakan salah satu bentuk media komunikasi visual yang terdiri atas informasi dan gagasan tentang suatu hal yang disajikan agar mampu mempengaruhi anak SD untuk memperoleh respon.

Video infografis ini dibuat dengan menggunakan beberapa elemen estetis visual seperti gambar, warna, audio dan tipografi sehingga video ini menjadi sangat menarik. Dari banyaknya elemen estetis yang digunakan maka dibutuhkan suatu software aplikasi Adobe After Effect agar seluruh komponen dapat saling terintegrasi. Diharapkan dengan adanya video infografis bahaya merokok ini, anak SD dapat memahami tujuan video dan memberikan respon seperti yang diharapkan. Dengan adanya kuisioner yang di ujikan kepada beberapa anak SD yang menunjukkan hasil nilai $75 \%$. Video infografis bahaya merokok untuk anak SD ini baik, maka dalam pembuatan video infografis ini mempunyai kelayakan untuk dipublikasikan sebagai pengetahuan dan sarana edukasi untuk anak SD tentang bahaya rokok.
\end{abstract}

Kata kunci: Infografis, Motion Graphic, Rokok, Sekolah Dasar, Video

\section{ABSTRACT}

Health is one important aspect in human's life. Nowadays, there are many disease that attack many people caused by bacteria, not only that bad habit and unhealthy lifestyle of human being also caused it. Smoking is one of unhealthy lifestyle. Moreover, smoking can give a horrible disease because cigarette contains of dangerous chemicals. If many children and teenagers have been started for being a smoker in their young age, there will be some bad impact that happen to them. Therefore, to prevent someone for being smoker, it will be better to use a media. One of the media that can be used is info graphic video.

Additionally, there were two ways to gather the data for making an info graphic video, those are interview and literature review. In design process, the researcher tried to make the children in Elementary School interested and understood the video easily by making the illustration, animation with the language and image that were easy for them. Besides, by giving motion graphics technique in this video, it would be interesting for them. Info graphic video is one of visual communication media that consisted of some information and ideas about something that affected the children to get some responses.

Info graphic video were made by busing some visual aesthetic elements such as images, colors, audio, and typography to make the video more interesting. In addition, it needed a software, Adobe After Effect, to make 
those visual aesthetic elements in order all of the components could be integrated each other's. The researcher expected the info graphic video about smoking made the children in Elementary School understood about the video and gave a good response. On the other hand, from the result of questionnaire that was given to the children in Elementary School, the researcher got 75\%. It means that the info graphic video was good for the children in Elementary School and it could be published as an educative media for Elementary School about the dangerous of smoking.

Keywords: Learning Media, Art Jaranan, Turangga Yaksa, Interactive Multimedia.

\section{PENDAHULUAN}

Kesehatan merupakan salah satu aspek terpenting bagi kehidupan manusia. Saat ini, banyak penyakit yang disebabkan tidak hanya melalui kuman atau bakteri, melainkan dari kebiasaan atau pola hidup yang tidak sehat. Kanker paru-paru, jantung koroner, stroke merupakan contoh-contoh dari penyakit yang ditimbulkan akibat merokok. Merokok mengganggu kesehatan, kenyataan ini tidak dapat dipungkiri. Banyak penyakit telah terbukti menjadi akibat buruk merokok, baik secara langsung maupun tidak langsung

Perokok di Indonesia tidak hanya di kalangan dewasa, namun sudah merambat ke kalangan anak-anak. Dalam artikel berjudul "Pengaruh Negatif Rokok Bagi Kesehatan di Kalangan Remaja", mengungkapkan bahwa data pada anak-anak berusia 10-16 tahun sebagai berikut: angka perokok <10 tahun (9\%), 12 tahun (18\%), 13 tahun (23\%), 14 tahun (22\%), dan 15-16 tahun (28\%) telah merokok (Azwar, 1997: 19). Kurangnya pengetahuan dan sikap negatif terhadap rokok serta dampaknya merupakan penyebab utama para anakanak merokok.

Kenyataan adanya siswa SD yang telah merokok tentu membuat keprihatinan. Hal ini disebabkan karena rokok mempunyai sifat membuat orang kecanduan. Padahal usia SD merupakan usia yang masih belia, Jika anak-anak sudah kecanduan rokok sejak kecil maka akan lebih sulit untuk dihentikan. Oleh karena itu, perlu dilakukan upaya untuk menghentikan kebiasaan ini pada anak SD yang sudah pernah merokok dan mencegah terjadinya kebiasaan merokok pada siswa yang belum pernah merokok. Salah satu cara yang bisa ditempuh adalah dengan memberikan pengetahuan tentang bahaya merokok.

Dengan semakin berkembangnya teknologi informasi, upaya untuk mencegah kebiasaan merokok ini dapat dilakukan dengan berbagai media. Salah satunya adalah media video infografis. Media ini menggabungkan ilustrasi, data dan visualisasi. Penyampaian informasi secara visual akan mampu menarik minat target. Media infografis lebih menarik karena selain elemen visual juga menggunakan motion (pergerakan) dan audio (musik/sound effect) yang dapat memperkuat informasi atau pesan yang ingin disampaikan Motion sendiri adalah tipe animasi yang menampilkan tulisan dan grafik, aplikasinya berorientasi pada obyek. Dan medianya berupa still images dengan format pixel atau vector, data video dan audio.

\section{PEMBAHASAN}

Perancangan 
Perancangan adalah konsep, fungsionalitas, dan keluaran grafis yang dimaksudkan untuk memecahkan suatu masalah. Tahapan dalam perancangan itu berhubungan dengan konsep, ide, data dan juga visualisasinya serta media yang akan digunakan, solusi dari permasalahan (Lankow, 2012: 19). Perancangan video infografis tentang bahaya merokok untuk anak SD menggunakan teknik motion graphics. Rokok adalah suatu produk yang dihasilkan dengan memotong daun-daun tembakau secara sempurna yang digulung atau diisi ke dalam suatu silinder yang disebut paper wrapped (secara umum kurang dari $120 \mathrm{~mm}$ panjangnya dan $10 \mathrm{~mm}$ garis tengah). Rokok dinyalakan dari awal hingga akhir dan dibiarkan membara lalu dihisap hingga keluar asapnya. Pada umumnya rokok memakai penyaring atau filter. Rokok dihisap langsung melalui mulut, tetapi ada juga yang dinyalakan dengan suatu pipa rokok (Husaini, 2006: 15).

\section{Elemen Desain}

Video dapat menyajikan informasi, menggambarkan suatu proses dan tepat mengajarkan keterampilan, menyingkat dan mengembangkan waktu serta dapat mempengaruhi sikap. Hal ini dipengaruhi oleh ketertarikan minat, dimana tayangan yang ditampilkan oleh media video dapat menarik gairah rangsang (stimulus) seseorang untuk menyimak lebih dalam. Secara empiris kata video berasal dari sebuah singkatan yang dalam bahasa inggrisnya yaitu visual dan audio. Kata vi adalah singkatan dari visual yang berarti gambar, kemudian pada kata deo adalah singkatan dari audio yang berarti suara. Dari penjelasan diatas dapat disimpulkan pemahaman bahwa video adalah merupakan seperangkat komponen atau media yang mampu menampilkan gambar sekaligus suara dalam waktu bersamaan. Pada dasarnya hakikat video adalah mengubah suatu ide atau gagasan menjadi sebuah tayangan gambar dan suara (Kemp, 1985: 221). Arsyad (2002:94) menyatakan karakteristik audio visual yaitu bersifat linear, menyajikan visual yang dinamis, digunakan dengan cara yang telah ditentukan sebelumnya oleh perancang, merupakan representasi fisik dari gagasan real atau abstrak, dikembangkan menurut prinsip psikologis behafiorisme dan kognitif, dan berorientasi pada guru. Menurut Media (2009:9) ada beberapa jenis video berdasarkan video yang mudah dibuat yaitu video blog, video musik, video parodi, video kampanye, dan video berita.

\section{Infografis}

Berdasarkan definisi semua grafis informasi ditujukan untuk mengkomunikasikan informasi. Yang berbeda-beda adalah tujuan penyampaian informasi itu dan pemahaman tentang tujuan inilah yang menentukan prioritas sebuah grafis. Prioritas-prioritas ini berperan dalam menentukan perbedaan yang perlu dalam pendekatan untuk tiap rancangan. Sebagai contoh jika sebuah infografis dimaksudkan untuk mengkomunikasikan informasi dengan cara yang sejelas mungkin dan tanpa bias sama sekali, maka prioritas utama bagi perancang adalah komprehensi, kemudian retensi dan setelahnya daya pikat. Kualitas konten atau grafis yang dihasilkan secara konsisten membantu mendorong minat dengan 
membangun kesan yang kuat kepada target. Kualitas sebuah publikasi didasarkan pada konten yang dihasilkan, yang dimaksutkan untuk membantu target memahami topik yang disajikan (Lankow , 2012: 38 ).

\section{Motion Graphic}

Motion graphics adalah grafis yang menggunakan video dan atau animasi untuk menciptakan ilusi dari gerak atau transformasi. Graphics design telah berubah dari static publishing dengan memanfaatkan teknologi komunikasi termasuk film, animasi, media inteaktif, dan environmental design. Bidang motion graphics telah menyebar melalui imajinasi para designer dan penonton di abad kedua puluh satu ini. Motion menjadi bagian utama modern visual saat ini dengan integrasi antara televisi, internet, dan lingkungan (Susanto, 2012: 2).

\section{Perancangan}

Permasalahan yang dikemukakan di awal adalah kurangnya pemahaman akan bahayanya merokok pada anak SD. Sebagai pemecahan tersebut maka dirancanglah sebuah video infografis yang bertujuan untuk memberikan pemahaman tentang rokok. Video ini memberikan informasi tentang rokok, dampak rokok, kandungan zat, dan faktor penyebab mereka merokok. Perancangan yang dibuat ini diharapkan mampu mencegah anak SD untuk merokok, dan menghentikan kebiasaan merokok yang sudah mereka lakukan. Pada pembuatan video infografis ini ada tiga tahapan dalam proses produksi, meliputi tahap visualisasi yang didalamnya terdapat proses perancangan atau pembuatan objek dan background, proses animasi objek dan background per scene, dan yang terakhir proses rendering. Tahap kedua adalah evaluasi keseluruhan video mencakup tampilan dan keefektifan. Kemudian tahap terakhir adalah tahap distribusi. Pengujian produk ini dituangkan dalam bentuk kuesioner. Kuesioner tersebut dibagikan kepada 18 orang dengan latar belakang adalah anak SD dari kelas 1 hingga kelas 6. Berikut adalah kuesioner beserta aspek penilaian dan hasil rekapitulasi kuesioner video infografis bahaya merokok.

Di dalam video infografis ini terdapat 3 karakter yaitu karakter Doni berusia 10 tahun, 12 tahun, dan 15 tahun. Setiap karakter akan muncul di setiap informasi dalam video. Ketika Doni berusia 12 tahun dia menceritakan bahwa dia merokok di usia 10 tahun, dan ketika karakter berada di usia 13 tahun muncul dalam informasi zat yang terkandung di dalam rokok. Karakter di usia 15 tahun untuk muncul sebagai perokok akif dan dampak penyakit karena rokok. Di dalam video infografis ini akan menampilkan objek-objek gambar yang nantinya mampu mendukung alur cerita. Di dalam cerita akan ada gambar toko, toko akan muncul di scene 5, sebagai bentuk bangunan yang akan dituju oleh Doni untuk membeli rokok. Ketika karakter berusia 12 tahun akan muncul bangunan sekolah SMP, bangunan ini sebagai latar background Doni, karakter juga digambarkan memakai seragam sekolah SMP. 
Ketika karakter menjelaskan karbon monoksida di scene 11, akan muncul gambar jalan raya, mobil, gedung bertingkat dan matahari. Objek-objek tersebut akan memberikan ilustrasi mobil berjalan di perkotaan yang penuh dengan kendaraan ketika siang hari.

Ketika di scene 12, akan muncul bangunan sekolah SMA. Sama seperti bangunan sekolah SMP, bangunan ini untuk menjelaskan bahwa Doni sudah SMA yang juga berguna sebagai penguat objek karakter yang sedang memakai seragam SMA.

Tabel 1. Storyboard

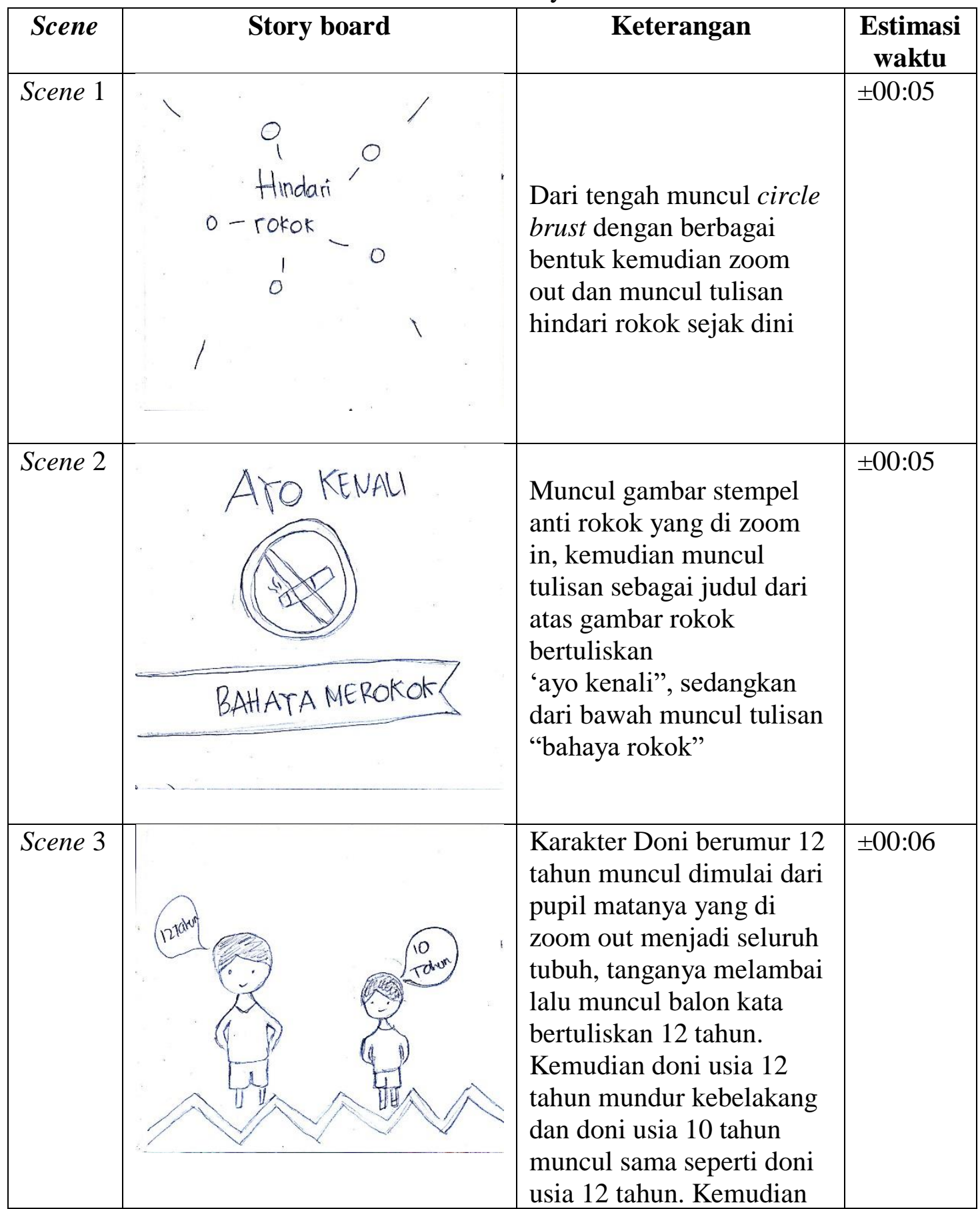




Scene 4 $\begin{aligned} & \text { doni usia 10 tahun mundur } \\ & \text { kebelakang sejajar dengan } \\ & \text { doni usia 12 tahun. } \\ & \text { Muncul segitiga dari } \\ & \text { bawah dan ada teks "apa } \\ & \text { penyebab doni merokok ?" }\end{aligned} \mid \pm 00: 07$




\begin{tabular}{|c|c|c|c|c|c|}
\hline Scene 7 & SNIKOTIN & $\underbrace{\triangle 10}_{\substack{\text { karbor } \\
\text { morofida? }}}$ & 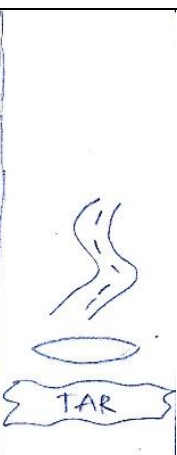 & $\begin{array}{l}\text { Gambar doni muncul dari } \\
\text { depan kemudian di zoom } \\
\text { in kesamping. Muncul } \\
\text { circle dari bawah dan } \\
\text { terdapat tulisan " } 4000 \\
\text { macam racun". Muncul } \\
\text { gambar } 3 \text { tangan dari } \\
\text { dalam circle akan } \\
\text { menggapai Doni }\end{array}$ & $\pm 00: 07$ \\
\hline Scene 8 & & & & $\begin{array}{l}\text { Gambar botol nikotin yang } \\
\text { bergerak ke tengan } \\
\text { kemudian menumpahkan } \\
\text { cairan putih, tumpahanya } \\
\text { akan menjadi coklat dan } \\
\text { ada cipratan air } \\
\text { menggunakan teknik trim } \\
\text { path. Muncul uapnya juga } \\
\text { yang berbentuk circle }\end{array}$ & $\pm 00: 07$ \\
\hline Scene 9 & Gatigut - & BATU BARA & - karu & $\begin{array}{l}\text { Ada circle yang telah di } \\
\text { trim path berada di tengan, } \\
\text { muncul tulisan } 43 \\
\text { kemudian berganti tulisan } \\
\text { TAR. Kemudian muncul } \\
\text { line yang telah di repeater } \\
\text { dan rotation dan tiap line } \\
\text { terdapat tulisan batu bara, } \\
\text { minyak bumi, gambut dan } \\
\text { kayu. Kemudian mengecil } \\
\text { dan berganti dengan } \\
\text { muncul cairan coklat di } \\
\text { tengah2, dan muncul } \\
\text { gambar mulut dengan gigi } \\
\text { berwarna putih, ketika } \\
\text { cairan tersebut mengecil } \\
\text { makan giginya akan } \\
\text { berwarna cokat. }\end{array}$ & $\pm 00: 04$ \\
\hline
\end{tabular}




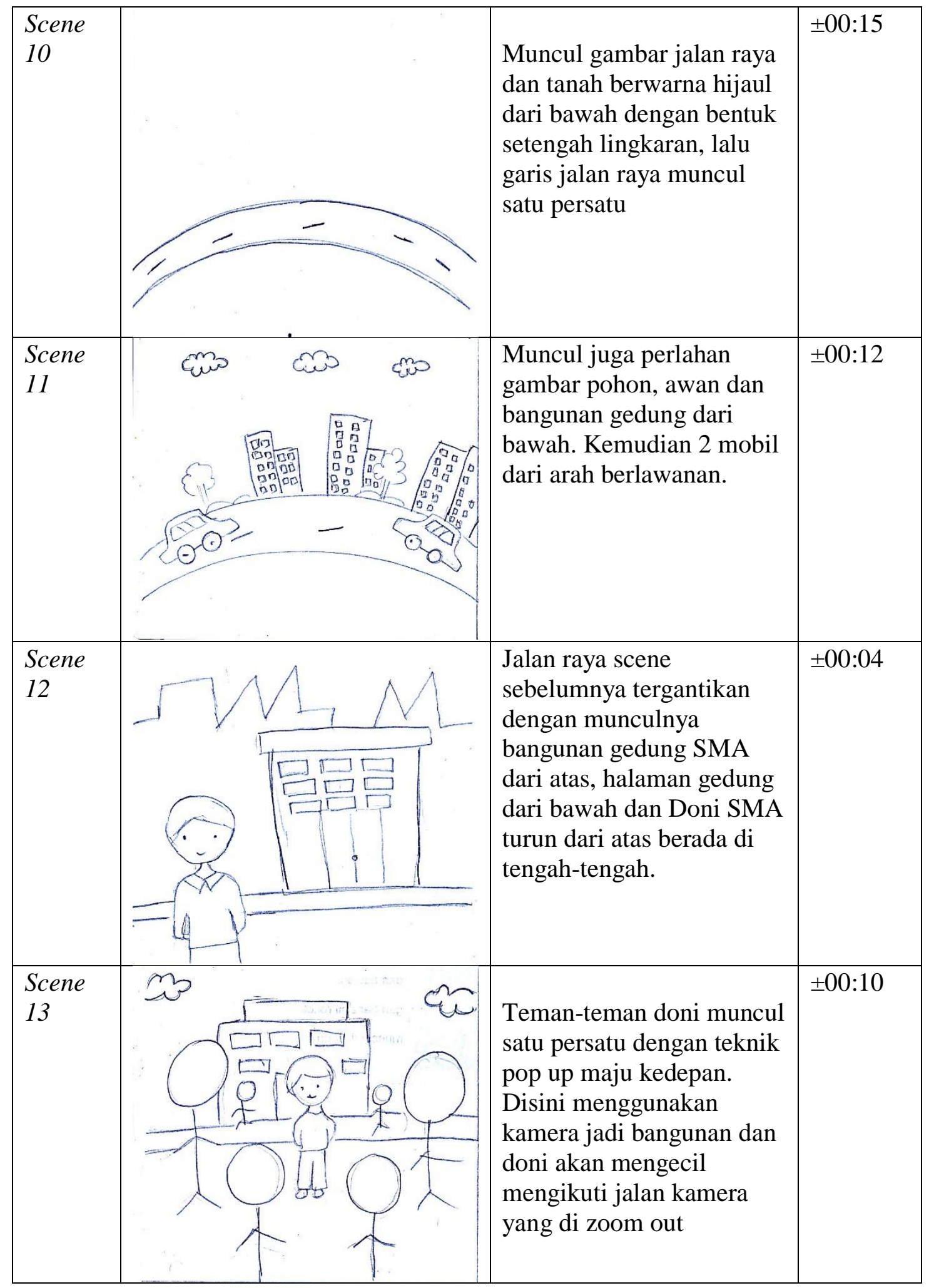




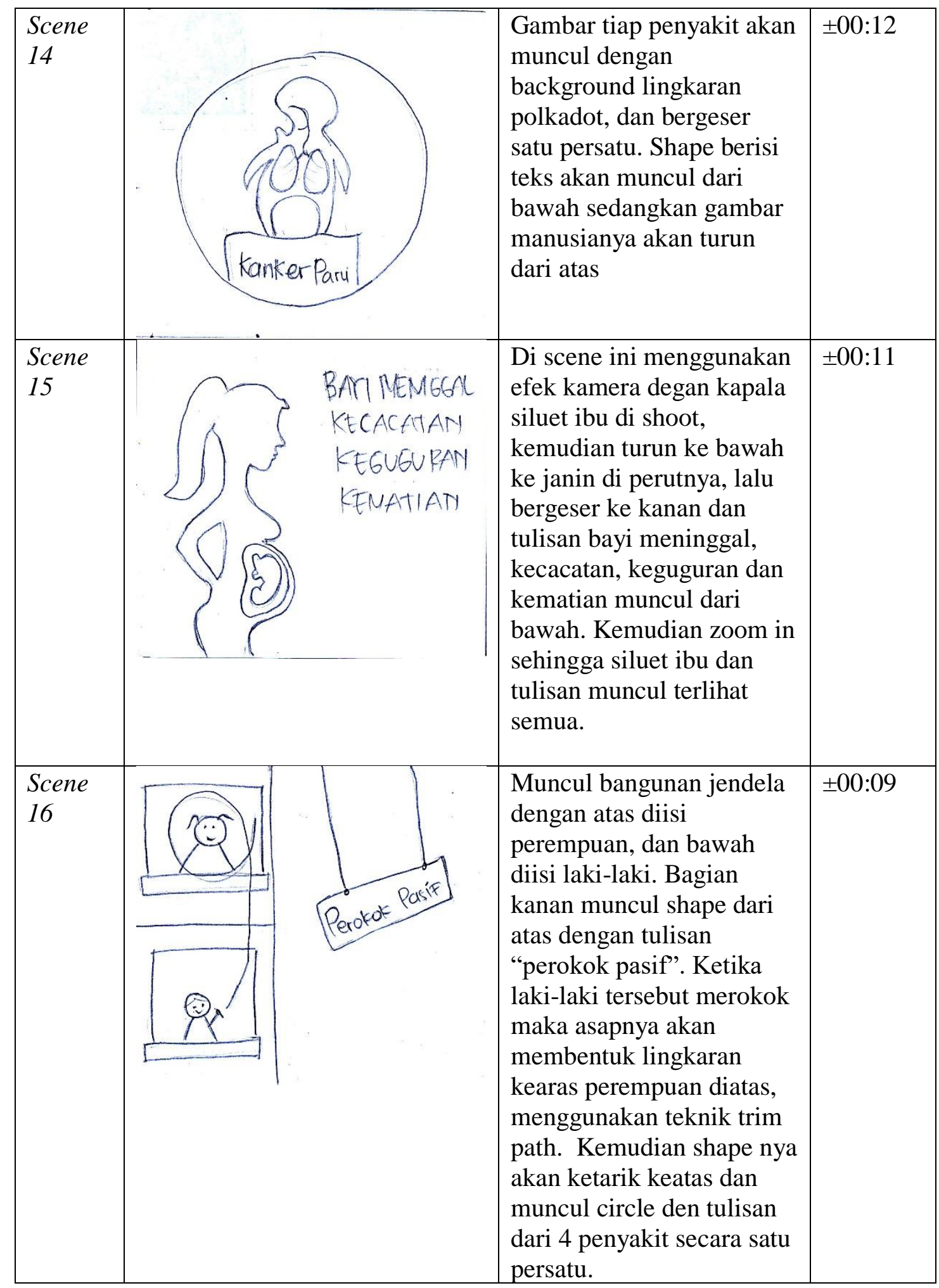




\begin{tabular}{|c|c|c|c|}
\hline $\begin{array}{l}\text { Scene } \\
17\end{array}$ & & $\begin{array}{l}\text { Muncul gambar doni, } \\
\text { dokter dan gedung rumah } \\
\text { sakit dari bawah, digabung } \\
\text { dengan teknik trim path } \\
\text { yang menghasilkan circle. } \\
\text { Disini menggunakan efek } \\
\text { kamera dengan gambar } \\
\text { kertas ulangan yang } \\
\text { disilang merah muncul dan } \\
\text { gambar doni mengecil di } \\
\text { belakangnya. Kemudian } \\
\text { gambar piala yang dicoret } \\
\text { muncul sehingga gambar } \\
\text { doni dan kertas ulangan } \\
\text { mengecil. }\end{array}$ & $\pm 00: 07$ \\
\hline $\begin{array}{l}\text { Scene } \\
18\end{array}$ & $\begin{array}{l}\text { Cara Menghindan } \\
\text { ROKOK } \\
\text { dengan cara }\end{array}$ & $\begin{array}{l}\text { Disini berisi tulisan cara } \\
\text { menghindari rokok dengan } \\
\text { cara. Tulisan rokok } \\
\text { menggunakan } 3 \text { efek } \\
\text { dengan teknik liquid. }\end{array}$ & $\pm 00: 03$ \\
\hline $\begin{array}{l}\text { Scene } \\
19\end{array}$ & & $\begin{array}{l}\text { Muncul gambar } 2 \text { karakter } \\
\text { kepala anak laki-laki yang } \\
\text { muncul dari tengah } \\
\text { mengecil lalu membesar, } \\
\text { dengan dilingkari shape } \\
\text { yang telah di trim path. } \\
\text { Lalu bergeser ke kanan } \\
\text { digantikan dengan gambar } \\
\text { permen dan buah-buahan. }\end{array}$ & $\pm 00: 10$ \\
\hline
\end{tabular}




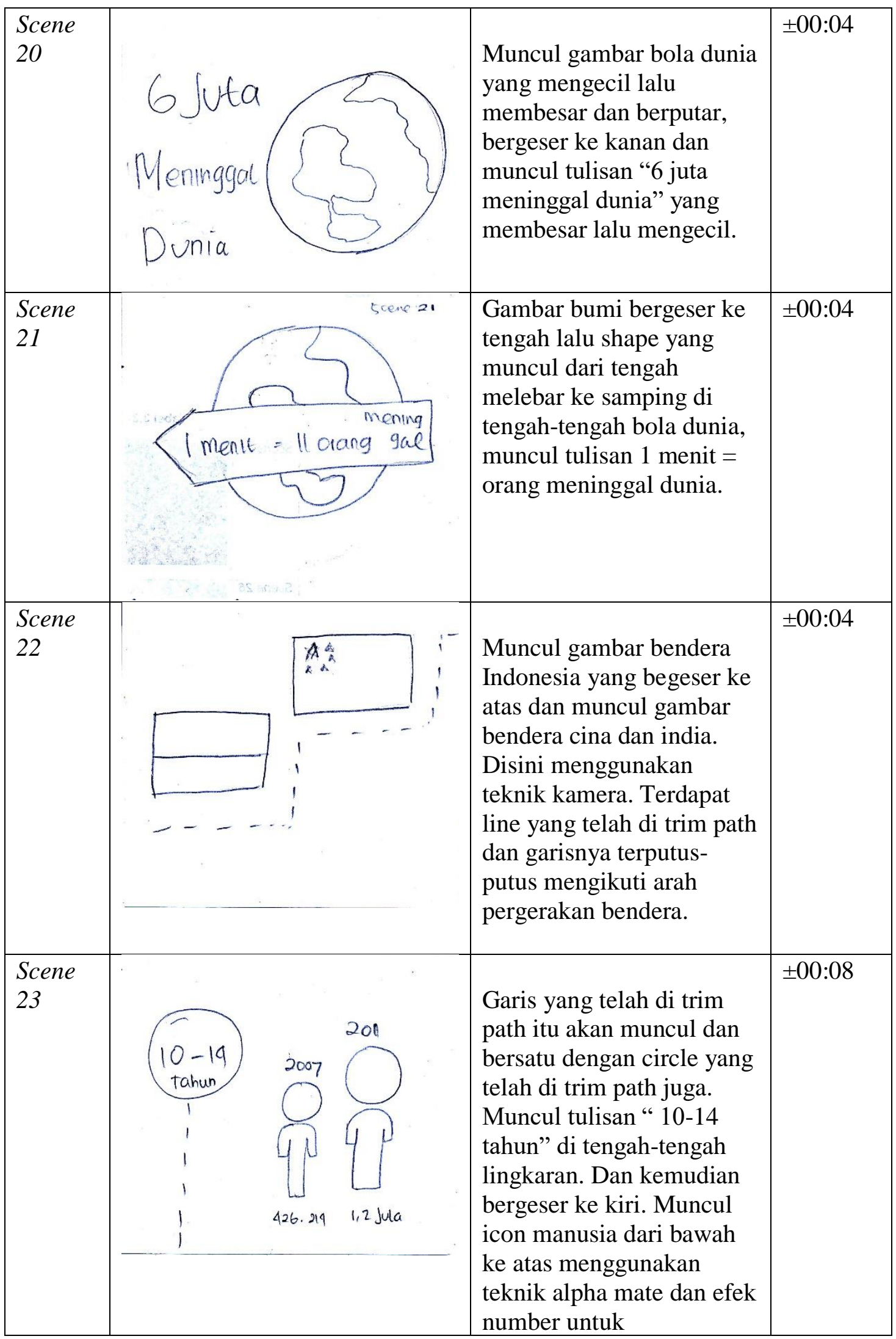




\begin{tabular}{|l|c|l|l|}
\hline $\begin{array}{l}\text { Scene } \\
24\end{array}$ & $\begin{array}{l}\text { memunculkan angka di } \\
\text { bawahnya. }\end{array}$ & \\
& Ayo teman toman & $\begin{array}{l}\text { sambar keempat karakter } \\
\text { doni muncul diap sisi } \\
\text { kanan dan kiri, muncul } \\
\text { dari bawah. Lalu dari arah } \\
\text { berlawanan jga muncul } \\
\text { tulisan sebagai peutup } \\
\text { video. Muncul shape yang } \\
\text { di zoom in dan doni usia } \\
10 \text { tahun muncul dari } \\
\text { bawah yang telah di alpha } \\
\text { mate. }\end{array}$ & \\
Sejak Dini & & \\
\hline
\end{tabular}

\section{KESIMPULAN}

Video ini menggabungkan animasi, suara dan gambar yang unik agar lebih menarik. Dirancang sedemikian rupa agar penjelasan informasi tentang rokok sesuai dengan usia target yang berada pada usia 6-12 tahun. Agar lebih efektif maka video dibuat dengan alur yang sederhana dan penggambaran objek yang terkesan anak-anak. Video akan bisa diakses kapan saja melalui internet untuk edukasi dan hiburan dengan mudah dan menyenangkan. Dengan adanya perancangan video infografis mengenai bahaya merokok untuk anak SD, diharapkan mampu menambah pengetahuan akan bahayanya rokok dan juga sebagai media informasi yang mudah dipahami.

\section{DAFTAR PUSTAKA}

Arsyad, A. 2002. Media Pembelajaran. Jakarta. Rajawali Pers. Husaini, Aiman. 2008. Tobat Merokok. Depok. Pustaka Iman.

Kemp, E, Jerrold. 1985. Planning and Producing Instructional Media. New York. Harpercollins College.

Lankow, Jason. 2012. Infographic : The Power Visual Storytelling. New Jersey. John Wiley dan Sons.

Media, Laksamana. 2009. Youtube dan Google Video. Yogyakarta. Mediakom.

Susanto, Dwi. Implementasi Teknik Motion Graphics Pada Pembuatan Profil Multimedia Broadcasting. Tugas Akhir tidak diterbitkan. Surabaya: Jurusan Telekomunikasi PENS ITS. 